\title{
Migration and transformation rule of heavy metals during the enzymatic hydrolysis for protein extraction in Sludge
}

\author{
Haijun $\mathrm{CaO}^{1, \mathrm{a}}$, Yulong $\mathrm{Li}^{2, \mathrm{~b}}$, Jin Wang ${ }^{3, \mathrm{c}}$, Shihong $\mathrm{Xu}^{4, \mathrm{~d}}$ and Dengxin $\mathrm{Li}^{*}$ \\ ${ }^{1}$ College of Environmental Science and Engineering ,Donghua University, Shanghai, \\ 201620, China \\ ${ }^{2}$ State Environmental Science and Engineering Center for Pollution Treatment and Control in \\ Textile Industry, Donghua University, Shanghai 201620, China
}

Keywords: Sewage sludge; enzymatic hydrolysis; heavy metals; Migration and transformation rule. Abstract. To understand the migration transformation rule of heavy metals in the process of extracting proteins from the sludge with enzymatic hydrolysis, this experiment studied the total amount of heavy metals in the sludge and the its morpHological change characteristics in the process, and the results showed that $\mathrm{Zn}, \mathrm{Pb}$ and $\mathrm{Cr}$ in the sludge have potential risk of migration, among them, $\mathrm{Zn}$ has higher mobility; the Exchangeable Form and Carbonate-Bound Form of $\mathrm{Cr}$ and $\mathrm{Pb}$ in the sludge is mainly converted into the Organio-Bound Form and Residual Form in the process. This technology, which is used to extract protein of sludge by enzymatic hydrolysis can stabilize the heavy metals in some way.

\section{Introduction}

The increasing number of sludge produced as a by-product has gotten more attention in recent years, because the urbanization is increasing rapidly, causing the increase in the amount of sewage treatment. Sludge is a very complicated mixture, being composed of large quantities of water, rich organic matter, nutrients, such as N, P, K, pathogens, parasitic ova, heavy metals and toxic organic pollutants[1].

The technique of using enzymatic hydrolysis to extract protein from sludge can efficiently transform solid waste, which uses enzymes to break down microbial cell walls and release the intracellular material [2,3].

This technique is also a method to stabilize heavy metals. During enzymatic hydrolysis, the decomposition of organic matter, cell rupture and the change of $\mathrm{pH}$ will have effect on the speciation of heavy metals and that will make the unstable states of heavy metals in sludge transform into stable states. Therefore, the reactions of heavy metals with the enzymes, the organic matter and the microorganisms in the sludge can produce an effect on the enzymatic hydrolysis, and thus, the quality of the product. In recent years, many researches has been conducted on the migration and transformation of heavy metals, but not so much on these happening in the sludge enzymatic hydrolysis process[4]. So it was necessary to study the migration and the transformation rule of heavy metals during the enzymatic hydrolysis process.

This research studied the changes in the concentrations and the speciation distribution of heavy metals during the enzymatic hydrolysis, exploring the migration and transformation rule of the heavy metals in the suldge. Consequently, this research may be able to support for the disposal of sludge.

\section{Materials and methods}

\section{Chemicals and reagents}

The sludge sampling site was the Qingpu District sewage treatment plant in Shanghai. A sample of residual sludge was stored in a thermal insulation device covered with ice, transported to the research laboratory in 1 hour, and preserved in a refrigerator at $4 \pm 0.5^{\circ} \mathrm{C}$.

Alkaline protease (AR), $\mathrm{CH}_{3} \mathrm{COOH}(\mathrm{AR}), \mathrm{CH}_{3} \mathrm{COONH}_{4}$ (AR) , $\mathrm{CH}_{3} \mathrm{COONa}$ (AR), $\mathrm{NH}_{2} \mathrm{OH} \cdot \mathrm{HCl}(\mathrm{AR}), \mathrm{HNO}_{3}(\mathrm{AR}), \mathrm{MgCl}_{2}(\mathrm{AR})$ were all from SinopHarm Chemical Reagent Co. Ltd. (China). 


\section{Apparatus and experimental procedure}

Experiments to extract protein from sludge by enzymatic hydrolysis were conducted under optimal experimental conditions: temperature at $55^{\circ} \mathrm{C}$, enzymatic hydrolysis duration of $4 \mathrm{~h}$, solid-to-liquid ratio of $1: 4$, dosage of enzyme at $3 \%$, and $\mathrm{pH}$ at $8[2,3]$.

Fresh sludge $(5 \mathrm{~g})$, deionized water $(20 \mathrm{~g})$ and the alkaline protease $(0.15 \mathrm{~g}, 3 \%)$ were mixed in a beaker, which was placed in a water bath (THZ-82, China) with a thermostatic mixer. The $\mathrm{pH}$ was adjusted to 8 with $\mathrm{NaOH}$ or $\mathrm{HCl}$. The sludge was treated by continuous enzymatic hydrolysis at $55^{\circ} \mathrm{C}$. After $1 \mathrm{~h}, 2 \mathrm{~h}, 3 \mathrm{~h}$, and $4 \mathrm{~h}$ of enzymatic hydrolysis time, the bath was inactivated for 10 minutes, then the sample was centrifuged (SL 16R, America) for 15 minutes. Both concentrations and speciations of the heavy metals in the enzymatic hydrolysis liquid and residue after separation were measured. The concentrations were determined by digesting the samples with $\mathrm{HCl}-\mathrm{HNO}_{3}-\mathrm{HClO}_{4}$ [5], and the speciation was detected by using the Tessier method. The digestion suspensions were filtered $(0.45$ um), and then the total metal concentrations in the filtrates were measured, using inductively coupled plasma atomic emission spectroscopy (ICP-AES, Prodigy XP, America). The experiment was carried out in triplicate.

The $\mathrm{pH}$, moisture content, SS, and VSS of the sludge samples were also measured by emloying the gravimetric method[6]. The efficiency of Protein extraction was measured by using Kjeldahl determination[7]). For all analyses, the variation of the replicates for each sample, including the blank control, was below $5 \%$.

\section{Results}

Analysis data of sludge

Some analysis data of sludge are shown in Table 1.

Table 1 Analysis of sludge.

\begin{tabular}{ll}
\hline Parameter & sludge \\
\hline Moisture content & $84.22 \%$ \\
Protein extraction efficiency & $52.4 \%$ \\
Organic matter reduction rate & $63.07 \%$ \\
$\mathrm{VSS}$ & $11.05 \%$ \\
$\mathrm{pH}$ & 6.85 \\
$\mathrm{Zn}$ & $2115.1 \mathrm{mg} / \mathrm{kg}$ \\
$\mathrm{Pb}$ & $5.4 \mathrm{mg} / \mathrm{kg}$ \\
$\mathrm{Cr}$ & $38.9 \mathrm{mg} / \mathrm{kg}$ \\
\hline
\end{tabular}

\section{The speciation distribution of heavy metals}

Enzymatic hydrolysis obviously changes any existing forms of heavy metals in sludge. According to the Tessier method, the speciation of heavy metals can be divided into five parts: F1 (Exchangeable), F2 (Bound to Carbonates), F3 (Bound to Fe-Mn Oxides), F4 (Bound to Organic Matter), and F5 (Residual). The sequence of the bio-availability and mobility of the speciation, from the strongest to the weakest, is: $\mathrm{F} 1>\mathrm{F} 2>\mathrm{F} 3>\mathrm{F} 4>\mathrm{F} 5$.

The speciation distribution of heavy metals in the raw sludge

Fig. 1 shows the speciation distribution of heavy metals in the raw sludge. In the original sludge, the ratios of various forms of heavy metals were respectively shown as follows: $\mathrm{Zn}(\mathrm{F} 1$ (45.0\%), F3 (29.2\%), F4 (10.6\%), and F5 (10.5\%)), Cr(F1 (33.0\%), F3 (11.4\%), F4 (21.1\%), and F5 (30.4\%)) and $\mathrm{Pb}(\mathrm{F} 1(21.4 \%), \mathrm{F} 2(0 \%), \mathrm{F} 3(0.1 \%), \mathrm{F} 4(0 \%)$, and F5 (78.5\%)), suggesting that the Zn had strong bio-availability and mobility, $\mathrm{Pb}$ mainly existed in the stable state(F5). 


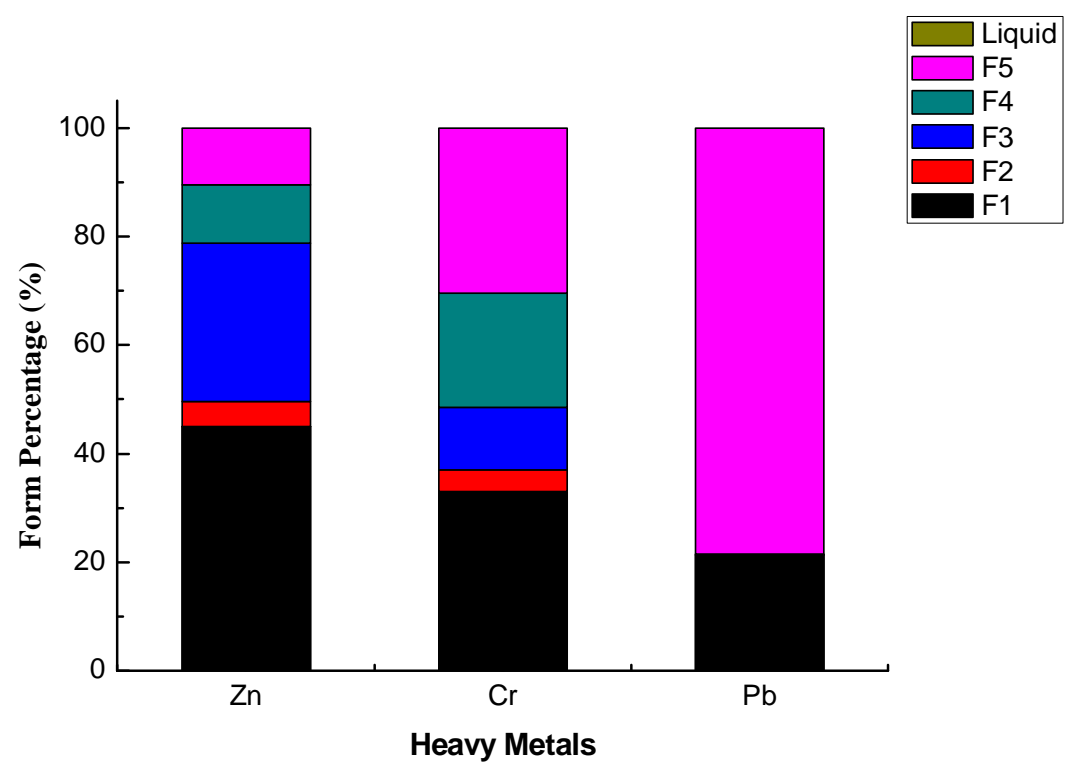

Fig.1.Speciation distribution of heavy metals in the raw sludge

\section{The speciation distribution of heavy metals at $2 \mathrm{~h}$ of hydrolysis time}

Fig. 2 displays the speciation distribution of heavy metals at $2 \mathrm{~h}$ of enzymatic hydrolysis. Zn mainly existed in the forms of F3 (63.1\%) and F4 (17.1\%). And Cr mainly existed in three forms, F3 (18.5\%), F4 (27.4\%), and F5 (47.8\%), the contents of F3, F4, and F5 were observed to increase. Meanwhile, the main forms of $\mathrm{Pb}$ were $\mathrm{F} 5$ (71.4\%) and the enzymatic hydrolysis liquid (27.2\%), indicating that had not played a role in the stabilization of $\mathrm{Pb}$, but $\mathrm{Pb}$ was stable in the process of enzymatic hydrolysis.

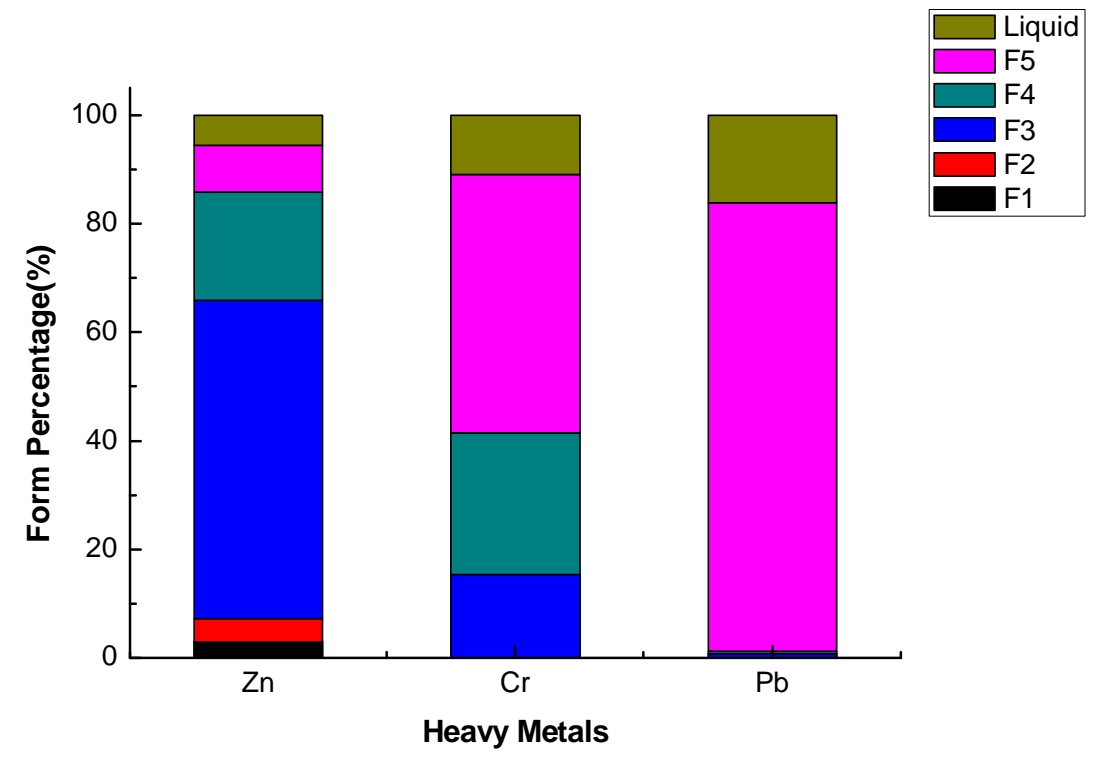

Fig.2.Speciation distribution of heavy metals at $2 \mathrm{~h}$ of hydrolysis time

\section{The speciation distribution of heavy metals at $\mathbf{4 h}$ of hydrolysis time}

Fig. 3 reveals the speciation distribution of heavy metals at $4 \mathrm{~h}$ of enzymatic hydrolysis. The contents of heavy metals including various forms changed a little by comparing Fig.2 with Fig.3, suggesting that the enzymatic hydrolysis process was nearly over. Zn existed in six forms, F1 (2.7\%), F2 (4.6\%), F3 (63.1\%), F4 (17.1\%), F5 (7.9\%), and the enzymatic hydrolysis liquid (4.6\%), suggesting that the enzymatic hydrolysis process had played a certain role in the stabilization of $\mathrm{Zn}$. 
When the enzymatic hydrolysis was over, the existing forms of Cr were F1 (0\%), F2 (0\%), F3 (17.2\%), F4 (27.6\%), F5 (49.7\%), and the enzymatic hydrolysis liquid (5.5\%), manifesting that the enzymatic hydrolysis process had played a very great part in the stabilization of $\mathrm{Cr}$. The existing speciation of $\mathrm{Pb}$ was F1 (0\%), F2 (0\%), F3 (0\%), F4 (0.9\%), and F5 (89.0\%), and the enzymatic hydrolysis liquid $(10.1 \%)$, turning out that the enzymatic hydrolysis process had not been very effective on the stabilization of $\mathrm{Pb}$.

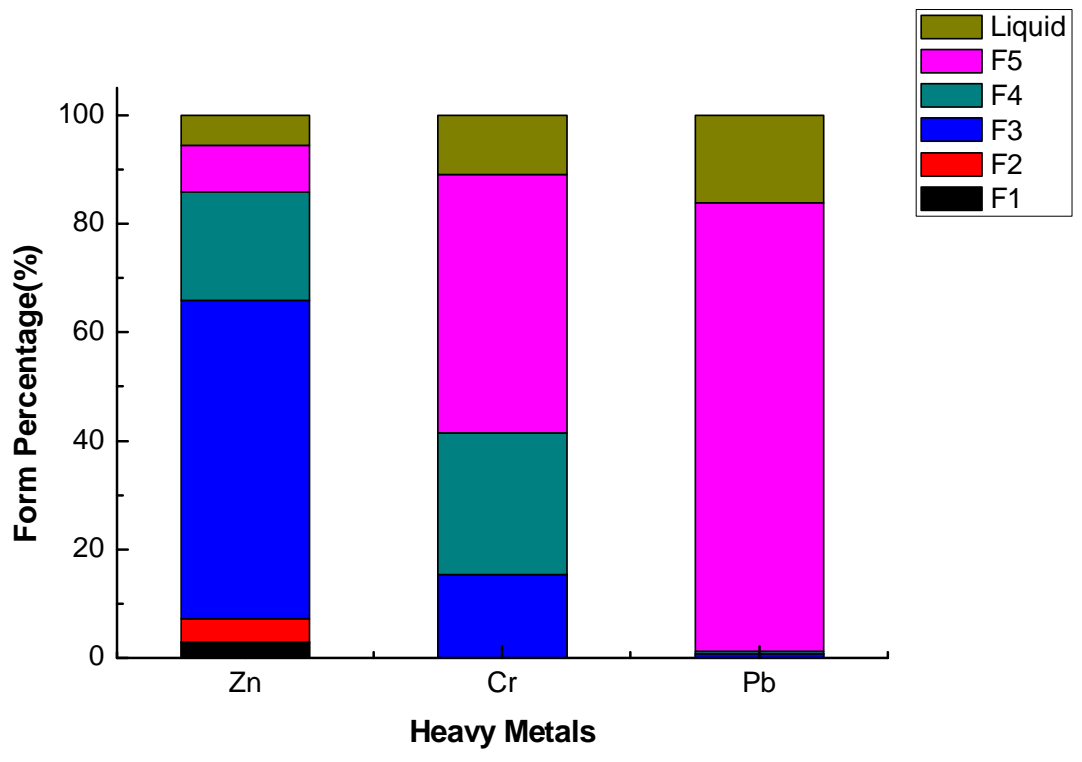

Fig.3.Speciation distribution of heavy metals at $4 \mathrm{~h}$ of enzymatic hydrolysis time

\section{Discussion}

Under $8 \%$ of total $\mathrm{Zn}$ in the sludge was in the unstable phase (F1 and F2) after enzymatic hydrolysis, and this result was better than the result obtained by Walter I. et al.[8]. Some researchers showed that $\mathrm{Fe}^{2+}$ and $\mathrm{Zn}^{2+}$ can inhibit enzyme activity by inhibiting the contact point of the enzyme catalyst when they are at higher concentrations, and this conclusion explains why the enzymatic hydrolysis process had not been very effective on the stabilization of $\mathrm{Zn}[9]$.

After enzymatic hydrolysis, over 77\% of $\mathrm{Cr}$ in the sludge was in the stable pHase (F4 and F5) and this result had also been proved by other authors [10].

Over $89 \%$ of total $\mathrm{Pb}$ in the sludge existed in the residual and this agrees with the results of Wong. et al.[11]who pointed out that $\mathrm{Pb}$ was mainly associated with the primary minerals in sewage sludge produced in Hong Kong. Smith S R[12] has shown that the heavy metals in the sludge can bound the complex organism and organic matter, and $\mathrm{Pb}$ is the strongest bound metal.

All the patterns above maybe make a difference to not only the technique to extract proteins in the sludge with enzymatic hydrolysis, but also the disposal of sludge. However, the mechanism of heavy metals in the process of the enzymatic hydrolysis needs to be studied by more methods.

\section{Conclusions}

The migration and transformation rule were studied in this paper. In the raw sludge, the content including $\mathrm{F} 1$ and $\mathrm{F} 2$ of $\mathrm{Zn}$ and $\mathrm{Pb}, \mathrm{Cr}$ respectively accounted for more than $25 \%$ of the total, and the ratio (F1 and F2) of $\mathrm{Zn}$ was more than $45 \%$. These showed that $\mathrm{Zn}, \mathrm{Pb}$ and $\mathrm{Cr}$ all have potential risk of migration, and $\mathrm{Zn}$ has the highest mobility.

The process of enzymatic hydrolysis had strongest stable effect on Cr. After the enzymatic hydrolysis, $\mathrm{Cr}$ and $\mathrm{Pb}$ mainly existed in the stable states of $\mathrm{F} 4$ and F5, and their ratios (F4 and F5) were 
$77.3 \%$ and $89.9 \%$ respectively. Therefore, the technology to extract protein with enzymatic hydrolysis has certain stability for heavy metals in the sludge.

\section{Acknowledgements}

This work was financially supported by Specialized Research Fund for the Doctoral Program of Higher Education of China (20130075110006), "Textile light" application basic research of China (J201503) and The Fundamental Research Funds for the Central University(15D111321).

\section{References}

[1] Wong J.W.C., Li K., Fang M., et al.: Toxicity evaluation of sewage sludge in Hong Kong. Environ. Int. 27, 373-380. (2001)

[2] Zhang W-f, Su R-j, Li D-x, Yang M: Extraction of amino acids from excess activated sludge by enzymatic enzymatic hydrolysis. Journal of Donghua University (English Edition). 30, 44-8. (2013)

[3] Su R, Shi P, Zhu M, Hong F, Li D: Studies on the properties of grapHene oxide-alkaline protease bio-composites. Bioresource Technolo. 115, 136-140. (2012)

[4] Leng L, Yuan X, Huang H, Jiang H, Chen X, Zeng G: The migration and transformation behavior of heavy metals during the liquefaction process of sewage sludge. Bioresource Technolo. 167, 144-150. (2014)

[5] Quevauviller P, Rauret G, LopezSanchez JF, Rubio R, Ure A, Muntau H: Certification of trace metal extractable contents in a sediment reference material (CRM 601) following a three-step sequential extraction procedure. Sci. Total Envir. 205, 223-234.( 1997)

[6] American Public Health Association: Standard methods for the examination of water and wastwater, 20th edn. American Public Health Association, Washington, D.C. (1998)

[7] Liu Y, Kong S, Li Y, Zeng H: Novel technology for sewage sludge utilization: Preparation of amino acids chelated trace elements (AACTE) fertilizer. J. Hazard. Mater. 171, 1159-1167. (2009)

[8] Walter I., Martínez F., Cala V.: Heavy metal speciation and pHytotoxic effects of three representative sewage sludges for agricultural uses. Environmental Pollution. 139, 507-514. (2006)

[9] Poll C, Thiede A, Wermbrer N, et al: Micro-scale distribution of microorganisms and microbial enzyme activities in a soil with long-term organic amendment. European Journal of Soil Science. 54(4), 715-720. (2003)

[10]Canet R., Pomares F., Tarazona F.: Chemical extractability and availability of heavy metals after seven years application of organicwastes to a citrus soil. Soil Use Manage, 13, 117-121. (1997)

[11]Wong J.W.C., Li K., Fang M., et al.: Toxicity evaluation of sewage sludges in Hong Kong. Environ. Int. 27, 373-380. (2001)

[12] Smith S.R: A critical review of the bioavailability and impacts of heavy metals in municipal solid waste composts compared to sewage sludge. Environment International. 35(1), 142-156. (2009) 